\title{
Clean car programme falling short of goal
}

[WASHINGTON] One of the Clinton administration's flagship technology programmes will not meet its main goal of developing by 2004 a competitively priced, family-sized 'clean car' that does 80 miles to the gallon, according to a National Research Council (NRC) expert panel.

The panel says the Partnership for a New Generation of Vehicles (PNGV), bringing together the federal government and the 'big three' US car-makers - General Motors, Ford and Chrysler - will need more money and a sharper focus on research and development problems if it is to meet the target.

Substantial progress has been made on several key technologies, such as fuel cells and lithium-ion batteries, says the NRC panel. But other major problems remain unresolved, such as the development of flywheels or large capacitors for energy storage.

As a result, the partnership's plan to select viable technologies this year for the car to be built in 2004 is "untenable", says the panel. That would force the programme to support only the most conservative options - such as diesel engines - and to discard the more difficult technologies which hold greater long-term promise.

The panel also says that the programme is continuing to put money into technologies, such as large capacitors, that have little potential to help PNGV meet its goals. And it has neglected vital problems that lack appeal to engineers, such as reducing the power consumption of car heating, cooling and lighting systems.

Trevor Jones, chairman of the NRC panel and of Echlin, a major US car parts supplier, says PNGV "should focus research on these areas that need major breakthroughs". He says the Clinton administration has done a good job of coordinating the programme, but has had trouble with the Congress in transferring money between elements of it as needed. PNGV has a budget this year of $\$ 270$ million, spread across four government departments and several smaller agencies.

In a joint statement, the government and its three partners said that they were "pleased that the review recognised the significant progress PNGV has made" in the past year. "The formidable challenges were known from the start," the statement said. "The partners remain enthusiastic about the prospects of the program and its ultimate benefits to the nation."

Ron York, PNGV director at General Motors, says that the programme is likely to adjust its technology selection process to ensure that work continues on items of longterm potential. He says that "the industry side will be recommending to the govern-

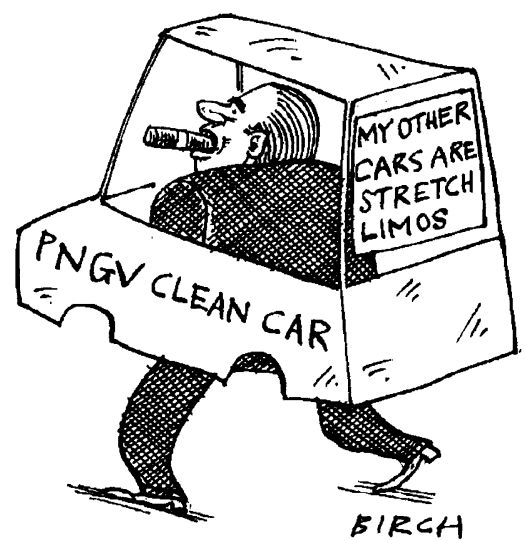

ment that work continues on these" as the car manufacturers move resources towards building prototypes.

"It's very hard to communicate how hard this kind of work is," says York. "We didn't get to the moon in one giant leap. If this was easy, we'd have done it a long time ago."

Some Republicans in Congress were initially critical of PNGV, which they saw as "corporate welfare", but the car-makers have had some success in convincing them of its value, and last year it was budgeted at a steady level. But the programme does not look well-placed to obtain the unspecified additional funding that the NRC report calls for.

ColinMacilwain

\section{US supercomputer centres to concentrate on networking}

[WASHINGTON] Two distributed supercomputer centres to be supported by the National Science Foundation (NSF) will give US university researchers quicker access to the most advanced supercomputer systems than has been possible with the existing four centres, NSF officials have promised.

The directors of the two centres, at the University of California at San Diego and the University of Illinois at Urbana-

Champaign, pledged a 'seamless' transition for the users of the two other centres, which will now lose NSF support, and promised that their new annual budgets of around $\$ 30$ million will allow more frequent hardware upgrades. Both centres also plan to help their users tap into far larger supercomputers being installed at the US nuclear weapons laboratories.

According to Bob Borchers of the NSF's computing directorate, the new centres will spend about one-third of their money on hardware, one-third on operations at their headquarters, and the rest on operations at their distributed partners' sites.

Larry Smarr, director of the Illinois centre, says the idea for its distributed approach - linking the processing power of supercomputers at different centres - arose when an experimental network was set up between 50 universities and laboratories for a supercomputing trade show in 1995. "That was such a phenomenal thing," he says. "For three days, we were living as though it was the 21 st century."

The Illinois centre, which will lead a partnership called the National Computational Science Alliance, will use computers built by Cray Research (now part of Silicon Graphics) and plans to concentrate on creating a high-speed network, linking together its dozens of university and industrial partners.

The San Diego centre will use IBM hardware, and is already negotiating a deal with the Lawrence Livermore National Laboratory to access part of an extremely powerful IBM machine being installed there for nuclear weapons research.

But managers of the centres that will now lose funding, at the University of Pittsburgh, Pennsylvania, and Cornell University, New York, are complaining bitterly about the NSF's selection process, and warn that their users could face a difficult transition. Their complaints will be aired this week at a hearing of the basic science subcommittee of the House of Representatives' Science Committee.

Cornell unsuccessfully challenged the selection process in February. "I have concerns that the process had a fair number of flaws in it," says Norman Scott, vicepresident for research at Cornell. "It wasn't up to the high standards we normally subscribe to the National Science Foundation."

The process that led to the selection of San Diego and Illinois by the National Science Board on 28 March was dogged by the disqualification of many reviewers and board members who were associated with one of the dozens of collaborating institutions involved in the four rival bids.

Scott also says many users are sceptical about the prospects for a smooth transition to the new centres, and that the small amount of NSF funding - \$11 million over two years - for Cornell to wind down its operations has "surprised us dramatically".

But Borchers says the two winners were "qualitatively better, and highly complementary to each other. They went beyond what we thought the vision would be, and offered a broader approach which was really rather compelling". 